\title{
Spatial integration of rice markets: The case of Kwara and Niger States, Nigeria.
}

\author{
Ojo A. O., K. M. Baba L. Tanko, O. B., Adeniji and M. A.Ojo \\ Department of Agricultural Economics and Extension Technology, \\ Federal University of Technology, P.M.B. 65, Minna, Niger State, Nigeria
}

\begin{abstract}
This study examined whether rice markets in Kwara and Niger States, Nigeria are integrated or not. Secondary data of retail prices of rice were collected for a period of 60 months (2006-2010) and error correction technique was employed in the determination of the degree of market integration between the two States using a four test procedures viz: Augumented Dickey Fuller test to detect for the presence of unit root in the series; Johansen co-integration test for the long run equilibrium relationship among the variables; vector error correction model test (VECM) to capture short-run and long-run changes in the price movements; and Granger casualty test to reflect the direction of influence between prices. The overall analysis of the vector error correction estimates shows that most of the markets in the two states were not well integrated in the short run. In other words, price adjustment across markets did not happen instantaneously. It took some times for the spatial price adjustments to take place. However, the co-integration results revealed that most of the markets in the two states were well integrated in the long run in the study area. The causality test results indicated that though the two States rice markets drifted apart in the short run, there was smooth transmission of price signals and marketing information from Kwara State to Niger State rice markets.
\end{abstract}

Key words: Co-integration, integration, vector error correction and rice markets

\section{Introduction}

of demand for rice, deviations from a normal price normally reflect uncontrollable Market integration refers to the co-movements of prices and the smooth transmission of price signals and information across spatially separated markets (Ghosh, 2000). When correct price signal is not conveyed, consumers' satisfaction cannot be guaranteed, production distortions will be prevalent and resultant proper functioning of the markets will be harmed. The usual definition in the literature is that integrated markets are those where prices are determined interdependently.

Given the price inelasticity supply shocks. An integrated market can mitigate the effect of such price shocks because it induces trade between surplus and deficit areas thereby ensuring stability of rice prices in the area. Conversely, price stability can induce investments in labour-intensive machinery, improving the efficiency of technology choice in low-wage economies as well as contribute to a stable political environment in which investors can form secure long-run expectations. The above factors led Timmer (2004) to conclude that food security and economic growth interact with each other in a mutually reinforcing process over the course of development. Therefore, an instrument to safeguard stability in food prices is market integration. The objective of this paper is to analyze the degree and extent of integration of rice markets in Kwara and Niger States, Nigeria.

\section{Conceptual framework:}

The model of spatial integration predicts that, under competitive conditions, price differences between two regions in the same economic market for a homogeneous commodity will approximately equal the interregional transportation costs. Market integration thus involves a test of price efficiency by examining how food markets in different regions respond jointly to supply and demand forces. If price movements in different parts of the country tend to behave similarly, reflecting the cost of transferring the product between two regions, then markets are said to be integrated. Several studies on market liberalization have tested for food market integration (Ravallion, 1986; Alexander and Wyeth, 1994 and Dercon, 1995). Early empirical studies of market integration used static price correlations to test for spatial market integration in agricultural markets (Jones, 1968; Harriss, 1979 and Blauch, 1997). This involves the estimation of bivariate correlation or regression coefficients between the time series of spot prices for an identical good at different market places. In these analyses, a statistically significant coefficient implies that the two markets are integrated. This kind of modeling of spatial market integration has been criticized for masking other. Some other past research work on market integration on various combinations of foodstuffs markets are Akwasi et al., (2011); Amikuzuno (2010); Mohammad and Verbeke, (2010); Okoroafor et al., (2010); Rahji and Adewunmi (2008); Daan, (2008); Mafimisebi, 2008; Tahir and Javed, 2007; Aminu (2006); Huang and Rozelle, (2006); Christine et al., (2005); Akande and Akpokodje 
(2003); and Takamatsu (2002). These studies suggest that the major sources of poor integration and inefficiency include the poor price information transmission channel, too many intermediaries and the high cost of transportation, as well as the sources and validity of price data. The price series used for the various studies were collected weekly or fortnightly by the researchers.

\section{Methodology}

The paper used secondary data of retail prices of rice for a period of sixty months (2006-2010) from Agricultural Development Projects offices in Kwara and Niger States respectively. Five different markets were randomly selected from each State. markets selected in Kwara State are Patigi (Yagba market), Offa (Owode market), Oke-oyi (Oke-oyi market), Oke-ero (Odo-owa market) and Malete (Malete market) while that of Niger State are Bida (New market), Maitumbi (Maitumbi market), Shiroro (Dandaudu market), Wushishi (Maito market) and Baddegi (Baddegi market). Some of the markets are rural markets while others are urban markets. Rural markets are the markets located within the area of production while urban markets are considered as those located outside the area of production. The rural markets are Malete, Oke-oyi and Odo-owa; and Dandaudu, Maito and Baddegi for kwara and Niger States respectively. Prices of rice in rural areas are expected to be lower than its prices in urban areas because of the proximity of the markets to the area of production. The selected markets had close proximity since any mode of transportation chosen can make delivery within one day. As such, all the markets in the study area are separated by a distance of less than 250 kilometers. Any distance above this is considered a far distance.

\section{Analytical techniques}

This study was achieved by analyzing the relationship between the two markets selected for the study (i.e rice supplying market and rice consuming market). For this study, rice supplying market is referred to as market A (Niger State) while rice consuming market is referred to as market B (Kwara State). Analysis of relationships between prices is a common tool in market integration analysis (Okoh and Egbon, 2005). The market integration model (showing the basic relationship to be investigated) is expressed as follows:

$\ln P_{B t}=\alpha+\beta \ln P_{A t}+\gamma \ln P_{B t-1}+\varepsilon_{i t}$

Where,

$\mathrm{P}_{A t}=$ the price of rice in $\mathrm{A}^{\text {th }}$ market on $\mathrm{t}^{\text {th }}$ month

$\mathrm{P}_{B t-l}=$ the price of rice in $B^{\text {th }}$ market on $t-1^{\text {th }}$ month

$\alpha=$ a constant term (the $\log$ of a proportionality coefficient) that captures transportation costs, and quality differences.

$\beta$ gives the relationship between the prices

$\gamma=$ the error correction term

$\varepsilon=$ white noise term.

Aprori conditions specify that if,

$\beta=1$, the law of one price holds and the relative price is constant. This implies that the two markets are perfectly spatially integrated, that is, a price change in the supplying market is fully reflected in the consuming market.

$0<\beta<1$, there is a relationship between the prices, but the relative price is not constant. The degree of integration is evaluated by investigating how far the deviation of $\beta$ is from unity.

\section{Test and estimation procedure}

The study employed Error Correction Models as suggested by Engle and Granger (1987). There are four steps in the application of the above technique. The first step involved carrying out a unit root test on univariate time series to determine the order of integration through successive differencing. Secondly, Johansen co-integration method was estimated using variables of the same order of integration. The residuals of the cointegration was tested for stationarity in the third step. Lastly, the Error Correction Model (ECM) was estimated. Step I: Using the Augmented Dickey- Fuller (ADF) test (Dickey and Fuller, 1979) the order of integration of each time series variable was tested to find out if the data are trend stationary or not. The ADF test for this study was formulated by these equations:

$$
\begin{aligned}
& \Delta P_{B t}=\beta_{0}+\beta_{t} P_{B t-i}+\sum c_{i} \Delta P_{B t-1}+\varepsilon_{t} \\
& \Delta P_{A t}=\gamma_{0}+\gamma_{t} P_{A t-i}+\sum d_{i} \Delta P_{A t-1}+\varepsilon_{t}
\end{aligned}
$$

Where,

$\Delta=$ the first difference operator

$\varepsilon_{\mathrm{t}}=$ the stochastic error term that follows the classical assumptions. 
The other variables in equations (2) and (3) remain as defined in equation (1). The null hypothesis in equations (2) and (3) is that unit root exists, that is, $\beta=\gamma=1$ against the alternative hypothesis, that $\beta \neq \gamma<1$

The decision rule here is that if the value of the ADF statistic is less than the critical value at the conventional significance level (usually the five per cent significant level) then the series $\left(P_{t}\right)$ is said to be stationary and vice versa. Once the series are found to be non-stationary, then there should exist a linear combination of these variables, which is integrated of order one. The general representation for equations (2) and (3) is:

$$
\Delta P_{i t}=\beta+\beta_{i} T+\delta_{i} P_{t-1}+\sum_{j=1}^{k} b_{i} \Delta P_{t-1}+\varepsilon_{t}
$$

Where,

$\Delta=$ the difference operator

$\mathrm{P}_{\mathrm{it}}=$ the price of rice in market $\mathrm{i}$, at time, $\mathrm{t}$ and $\mathrm{T}$ is a time trend (Dickey \& Fuller, 1979), $\beta=$ drift parameter.

$\beta_{\mathrm{i}}, \delta_{\mathrm{i}}$ and $\mathrm{b}_{\mathrm{i}}=$ coefficients

$\varepsilon_{\mathrm{t}}=$ white noise error term with zero mean and constant variance

$\Delta \mathrm{P}_{\mathrm{t}-1}=\left(\mathrm{P}_{\mathrm{t}-1}+\mathrm{P}_{\mathrm{t}-2}\right), \Delta \mathrm{P}_{\mathrm{t}-2}=\left(\mathrm{P}_{\mathrm{t}-2}+\mathrm{P}_{\mathrm{t}-3}\right)$ etc, that is, using lagged difference terms.

The number of lagged difference term to include is often determined empirically, the idea being to include enough terms so that the error term is serially independent (Gujarati, 1995).

Step2: The next logical step is to test for cointegration using Johansen co-integration techniques (Trace and Eigenvalue Test).

If two series are individually stationary at same order, the Johansen and Juselius (1990) and Juselius (2006) can be used to estimate the long run co-integrating vector from a Vector Auto regression (VAR) model of the form:

$$
\Delta_{p t}=\alpha+\sum_{i=1}^{k-1} \Gamma_{i} \Delta p_{t-1}+\Pi p_{t-1}+\mu_{t}
$$

Where:

$p_{t}$ is a $\mathrm{n} \times 1$ vector containing the rice price series at time $(\mathrm{t}), \Delta$ is the first difference operator. $\Gamma_{i}$ and $\Pi$ are $\mathrm{n}$ x n matrix of parameters on the $i^{\text {th }}$ and $k^{\text {th }} \operatorname{lag}$ of $p_{t}, \Gamma_{i}=\left(\sum_{i=1}^{k} A\right)-I_{g}, \Pi=\left(\sum_{i=1}^{k} A_{i}\right)-I_{g}, I_{\mathrm{g}}$ is the identity matrix of dimension $\mathrm{g}, \alpha$ is constant term, $\mu_{t}$ is $\mathrm{n} \mathrm{x} 1$ white noise vector. Throughout, $\mathrm{p}$ is restricted to be (at most) integrated of order one, denoted $1(1)$, where $1(\mathrm{j})$ variable requires $j^{\text {th }}$ differencing to make it stationary. Equation (5) tests the co-integrating relationship between stationary series. Johansen and Juselius (1990) and Juselius (2006) derived two maximum likelihood statistics for testing the rank of $\Pi$, and for identifying possible co-integration as the following:

$$
\begin{aligned}
& \lambda_{\text {trace }}(r)=-T \sum_{i=r+1}^{m} \operatorname{In}\left(1-\lambda_{i}\right) \ldots . \\
& \lambda_{\text {max }}(r, r+1)=-T \operatorname{In}\left(1-\lambda_{r+1}\right)
\end{aligned}
$$

Where,

$r=$ the co-integration number of pair-wise vector,

$\lambda_{i=} i^{\text {th }}$ eigenvalue's value of matrix $\prod$.

$\mathrm{T}=$ the number of observations.

$\lambda_{\text {trace }}$ is not a dependent test, but a series of tests corresponding to different $r$-value. $\lambda_{\max }$ tests each eigenvalue separately. The null hypothesis of the two statistical tests is that there is existence of $r$ co-integration relations while the alternative hypothesis is that there is existence of more than $\mathrm{r}$ co-integration relations.

Step III: This involved estimating the error correction model (ECM). ECM captures the short-run disequilibrium situations as well as the long-run equilibrium adjustments between prices. An ECM formulation, which describes both the short-run and the long-run behaviours of prices, is expressed as follows:

$$
\Delta P_{B t}=\gamma_{1}+\gamma_{2} \Delta P_{A t}-\pi \widehat{v}_{B t-I}+V_{i t}
$$

In this model,

$\gamma_{2}=$ the impact multiplier (the short-run effect) that measures the immediate impact that a change in $P_{A t}$ will have on a change in $P_{B t}$.

$\pi=$ the feedback effect or the adjustment effect that shows how much of the disequilibrium is being corrected, that is the extent to which any disequilibrium in the previous period affects any adjustment in the $P_{B t}$ period. Of course $\widehat{v}_{t-1}=P_{B t-1}-\widehat{\rho}_{1}-\widehat{\rho}_{2} P_{A t-1}$ therefore from this equation we also have $\rho_{2}$ being the long-run response. 
Step IV: This involved carrying out Granger casualty test. If a pair of series is co-integrated then there must be Granger-causality in at least one direction, which reflects the direction of influence between series (in this case, price).

$$
\begin{aligned}
& \Delta P_{B t}=\theta_{11} \Delta P_{B t-1}+\ldots+\theta_{1 n} \Delta P_{B t-n}+\theta_{21} \Delta P_{A t-1}+\ldots+\theta_{2 n} \Delta P_{A t-n}-\gamma_{1}\left(P_{B t-1}-\alpha P_{A t-1}-\delta\right)+\varepsilon_{1 t} \ldots . .(9) \\
& \Delta P_{B t}=\theta_{31} \Delta P_{B t-1}+\ldots+\theta_{3 n} \Delta P_{B t-n}+\theta_{41} \Delta P_{A t-1}+\ldots+\theta_{4 n} \Delta P_{A t-n}-\gamma_{2}\left(P_{B t-1}-\alpha P_{A t-1}-\delta\right)+\varepsilon_{2 t} \ldots(10)
\end{aligned}
$$

The following two assumptions will be tested using the above two models to determine the Granger causality relationship between prices.

$$
\begin{aligned}
& \theta_{21}=\Lambda=\theta_{2 n}=\Lambda=\gamma_{1}=0 \text { (No causality from } P_{B t} \text { to } P_{A t} \text { ) } \\
& \theta_{41}=\Lambda=\theta_{4 n}=\Lambda=\gamma_{2}=0 \text { (No causality from } P_{A t} \text { to } P_{B t} \text { ) }
\end{aligned}
$$

The above test (I - IV) procedures offer a framework for the assessment of price transmission and market integration.

\section{Results and Discussion}

Augumented Dickey-Fuller unit root test

Table 1 shows the results of the first step in testing market integration between the selected markets in the study area using the augmented Dickey-Fuller (ADF) test both at level and first difference which shows that all rice price series in the model were non-stationary at level both at $1 \%$ and $5 \%$ levels of significance. This implies that the price series contained unit root and are integrated of order one i.e $\mathrm{I}(0)$. The results in Table1 further showed that all the model variables were integrated of order one, I(1) after first differencing. Since the absolute value of the ADF is lower than their critical statistics, we fail to reject the null hypothesis of nonstationarity both at $1 \%$ and $5 \%$ levels of significance. The implication of this process is to avoid the consequences of regressing non-stationary time series with the antecedent problems of spurious results due to inflation and seasonality. This finding concur with earlier findings and conclusion by that food commodity price series are mostly stationary of order one, (Okoroafor et al., 2010 and Mafimisebi, 2008).

Table 1: Augmented Dicky Fuller unit root tests of price series in the study area

\begin{tabular}{lcc}
\hline Market Price Series & Price level & First Difference 1(1) \\
\hline Baddegi & $1(0)$ & -8.1495 \\
New market & -2.4925 & -6.9659 \\
Dandaudu & -1.9693 & -12.6721 \\
Maitumbi & -1.9182 & -9.4073 \\
Maito & -2.9082 & -8.3384 \\
Yagba & -1.5337 & -9.1384 \\
Malete & -2.5753 & -15.4622 \\
Oke-oyi & -1.8382 & -8.6151 \\
Odo-owa & -1.3362 & -12.1396 \\
Owode & -2.0918 & -10.2403 \\
\hline
\end{tabular}

Source: Compiled from the result of stationary tests

Note: Critical values are -3.561 and -3.5482 at the $99 \%$, and -2.9117 and -2.9126 at the $95 \%$ confidence levels for price levels and first difference series respectively.

\section{Interstate Pairwise co-integration between Kwara and Niger States}

The inter-state pairwise co-integration between Kwara and Niger rural and urban markets is shown in Table 2. It was observed, in respect to the rural markets in the two states, that the $\lambda$-trace and $\lambda_{\mathrm{i}}$-max.test statistics of 19.1502 and 17.4011 exceeded the critical values of 15.4947 and 14.2646 respectively at the convectional 5\% level which shows that there is a long-run linear relationship among the rural markets of the producing (Niger State) and consuming (Kwara State). For the kwara and Niger States urban markets, the test results in respect to the test statistics and critical values for both $\lambda$-trace and $\lambda_{i}$-max. also shows that there is a long-run linear relationship among the urban markets in the producing and consuming States. Therefore, they are integrated markets.

The overall analysis pinpoints to the fact that there is inter-dependence between rice markets in the two states. The markets operated as unified markets which is an indication that most of the markets adjusted significantly to price changes. This implies that rice markets in Kwara and Niger States during the study period were strongly linked together and therefore, the long-run equilibrium is stable. Shocks (deficit/surplus) from either State will quickly be transferred until equilibrium is (re)establisched, hence, according to Mafimisebi, 
Spatial integration of rice markets: The case of Kwara and Niger States, Nigeria.

2008, the arbitrage activities of marketers, who ship commodities (rice) between low and high price locations, will raise price in some markets whilst lowering them in others until price differentials equal transfer costs and all opportunities for earning excess profit have been exhausted.

Table 2: Interstate Pairwise co-integration between Kwara and Niger States

\begin{tabular}{lcc}
\hline Market Pairs & Trace Test Statistics & Maximal Eigenvalue Test Statistics \\
\hline Pi-Pj & $19.1502^{*}$ & $17.4011^{*}$ \\
Kwara (R) / Niger (R) & $21.7908^{*}$ & $19.2049^{*}$ \\
\hline
\end{tabular}

Source: Compiled from Co-integration Test Results

*Significant at 0.05 level

The critical values for trace test and maximal eigenvalue tests are 15.4947 and 14.2646 at $95 \%$ respectively.

\section{Error correction in rice market integration}

The vector error correction (VEC) estimate for rural markets in Kwara State is as presented in Table 3. It measures the short-run dynamics among rural rice markets and the result shows that with the exception of two, all the estimated short-run coefficients are statistically insignificant at the 5\% level. The value of the coefficients shows that the transmission of price changes from one market to another during the same month is weak. Adjustment to long-run equilibrium in the short-run revealed that price changes in Malete and Odo-owa during the period of study transmitted to other markets at a rate of $76 \%$ and $21 \%$ respectively per month which suggests that the adjustment process is very fast and slow for the former and latter respectively. Odo-owa market still showed faster adjustment process than the remaining markets in equation 2 (i.e 58\% for Odo-owa, $36 \%$ for Oke-oyi and $21 \%$ for malete). This implies that in the short-run, kwara rural markets were not well integrated. This finding is consistent with the work of Mohammad and Verbeke (2010) and Odularu (2010).

Table 3: Vector error correction estimates for rural markets in Kwara State

\begin{tabular}{lccc}
\hline Error Correction: & D(MALETE) & D(OKE-OYI) & D(ODO-OWA $)$ \\
\hline CointEq1 & -0.756813 & -0.001277 & 0.212129 \\
& $(0.25102)$ & $(0.28720)$ & $(0.33544)$ \\
& {$[-3.01496]$} & {$[-0.00445]$} & {$[0.63239]$} \\
CointEq2 & & & \\
& 0.206002 & -0.357302 & 0.583286 \\
& $(0.20887)$ & $(0.23897)$ & $(0.27911)$ \\
& {$[0.98629]$} & {$[-1.49518]$} & {$[2.08980]$} \\
\hline
\end{tabular}

Source: Compiled from VEC test results

Table 4: Vector error correction estimates for rural markets in Niger State

\begin{tabular}{lccc}
\hline Error Correction: & D(DANDAUDU) & D(MAITO) & D(BADDEGI) \\
\hline CointEq1 & -0.694122 & 0.158822 & 0.149337 \\
& $(0.25109)$ & $(0.17115)$ & $(0.17210)$ \\
& {$[-2.76438]$} & {$[0.92795]$} & {$[0.86773]$} \\
CointEq2 & & & \\
& 0.600966 & -0.28325 & 0.314297 \\
& $(0.23398)$ & $(0.15949)$ & $(0.16037)$ \\
\hline
\end{tabular}

Source: Compiled from VEC test results

\section{Vector Error Correction estimates for rural markets in Niger State}

Considering the adjustment coefficients as indicated in Table 4, it was discovered that the adjustment toward the long-run equilibrium in the short-run is fast for some markets and yet slow for others. For instance, in coint-equation 1, the rate at which price changes is transmitted to other markets is $69 \%$ for Dandaudu, Maito, $16 \%$ and Baddegi, $14 \%$. While in coint-equation 2, Dandaudu still took the lead of $60 \%$, followed by Baddegi, $31 \%$ and Maito, 28\%. The result also shows that all the estimated short-run coefficients are statistically insignificant at the 5\% level (with exception of two). The implication here is still in line with that of Kwara rural markets that the transmission of price changes from one market to another during the same month is weak. This implies that Niger State rural markets are not well integrated in the short run. 


\section{Vector Error Correction estimates for urban rice market in Kwara State}

Vector Error Correction estimates for urban rice market in Kwara State is as depicted in Table 5. The result shows that none of the estimated short-run coefficients was statistically significant at the $5 \%$ level. This invariably suggests that the transmission of price changes from one market to another during the same month is also weak. Adjustment towards the long-run equilibrium in the short-run is slow. This is because, within a month, price changes in Yagba and Owode were transmitted to other markets at a rate of $19 \%$ and $16 \%$ respectively. Based on the results, it is revealed that urban rice markets in kwara State are not well integrated in the short run as well.

\section{(d) Vector Error Correction estimates for urban rice market in Niger State}

Vector Error Correction estimates for urban rice market in Niger State (Table 6) revealed that all the estimated short-run coefficients were statistically significant at the 5\% level as opposed to that of urban markets in Kwara State. This shows that the transmission of price changes from one market to another during the period was strong. Adjustment towards the long-run equilibrium in the short-run also revealed that the price changes in New market and Maitumbi were transmitted to other markets at a rate of $34 \%$ and $63 \%$ respectively, within a month. Based on the results, it shows that urban rice markets in Niger State are moderately integrated in the short run.

Table 5: Vector error correction estimates for urban markets in Kwara State

\begin{tabular}{lcc}
\hline Error Correction: & $\mathrm{D}($ Yagba $)$ & $\mathrm{D}($ Owode $)$ \\
\hline CointEq1 & -0.189181 & 0.160393 \\
& $(0.09696)$ & $(0.10765)$ \\
& {$[-1.95107]$} & {$[1.48997]$} \\
\hline
\end{tabular}

Source: Compiled from VEC test results

Table 6: Vector error correction estimates for urban markets in Niger State

\begin{tabular}{ccc} 
Error Correction: & D(NEW MARKET) & D(MAITUMBI) \\
\hline CointEq1 & -0.343557 & 0.635710 \\
& $(0.13339)$ & $(0.21046)$ \\
& {$[-2.57558]$} & {$[3.02053]$} \\
\hline
\end{tabular}

Source: Compiled from VEC test results

\section{Inter-State Pairwise Granger-causality Test in Niger and Kwara Markets}

The finding for the inter-state pairwise Granger-causality in Niger and Kwara markets is indicated in Table 7. The null hypothesis of no causality is accepted for the uni-directional causality between rural/urban markets in Niger and rural/urban markets in kwara States at $1 \%$ probability level respectively. In other words, it is price changes in Kwara markets (either urban or rural) that drive the price formation in Niger State (either urban or rural). Though the two States rice markets may drift apart due to some factors such as non-stationary transaction costs, there is smooth transmission of price signals and marketing information from Kwara rice markets to Niger State rice markets.

Table 7: Inter-state Pairwise Granger-causality test on rural and urban rice markets in Niger and Kwara States

\begin{tabular}{lcc}
\hline Null hypothesis & F-Statistics & Probability \\
\hline Rural Niger $\rightarrow$ Rural Kwara & 1.2683 & 0.2897 \\
Rural Kwara $\rightarrow$ Rural Niger & $6.2212^{* *}$ & 0.0037 \\
Urban Niger $\rightarrow$ Urban Kwara & 1.7174 & 0.1894 \\
Urban Kwara $\rightarrow$ Urban Niger & $9.9576^{* *}$ & 0.0002 \\
\hline
\end{tabular}

Source: Compiled from the result of Granger-Causality Test

$*(* *)$ means significant at $5 \%(1 \%)$ level

$\rightarrow$ indicates direction of causality

\section{Conclusion and Recommendation}

This study examined spatial integration of rice markets in Kwara and Niger States, Nigeria. The overall analysis of the vector error correction estimates shows that most of the markets in the two states were not well integrated in the short run. In other words, price adjustment across markets did not happen instantaneously. It took some times for the spatial price adjustments to take place. However, the co-integration results revealed that 
most of the markets in the two states were well integrated in the long run in the study area. The causality test results indicated that though the two States rice markets drifted apart in the short run, there was smooth transmission of price signals and marketing information from Kwara State to Niger State rice markets.

Generally, market integration can have important implications for economic development as it can bring significant benefits to local residents and market stakeholders. For instance, the income of producers can be raised through increased specialization and trade as well as increasing the welfare of risk-averse consumers by reducing the variability of prices of goods that were previously non-tradable. Therefore, there is the need to improve infrastructure of the rice markets through efficient market information system that will tactically link marketers in the producing and consuming States together. The implication of this is that marketers will be able to adjust faster to changing price situations either in the rural or urban markets thereby reducing the risks and uncertainties embedded in ignorance of the happenings in the target/end markets.

\section{References}

[1] S. O. Akande and G. Akpokodje, Rice prices and market integration in selected areas in Nigeria: A study report on the Nigerian rice economy in a competitive world: constraints, opportunities and strategic choices. West Africa Rice Development Agency, 2003,10 .

[2] M. Akwasi, Akua Agyeiwaa-Afrane and John K. M. Kuwornu, Efficiency of the plantain marketing system in Ghana: A cointegration analysis, Journal of Development and Agricultural Economics 3(12), 2011, 593-601. http://www.academicjournals.org/JDAE

[3] C. Alexander and J. Wyeth, Cointegration and market integration: An application to the Indonesian rice market, Journal of Development Studies 30(2), 1994, 303-328.

[4] J. Amikuzuno, Spatial Price Transmission Analysis in Agricultural Markets: Does the Data Frequency Improve our Estimation?, A Paper presented at the 3rd AAAE International Conference, Cape Town, South Africa, September, 2010,19 - 23.

[5] A.Aminu, Pricing efficiency of tomato marketing in Jigawa State. Savannah Journal of Agriculture 1(1), 2006, 77-82.

[6] B. Blauch, Testing for food market integration revisited., Journal of Development Studies, 33, 1997, $477-487$.

[7] Christine Moser, C. B. Barrett and B. Minten (2005). Spatial integration of rice markets in Madagascar. USAID research paper.

[8] M. Daan, Unity Or diversity? On the integration and efficiency of rice markets in Indonesia, The Harvard-Hitotsubashi-Warwick Conference on Economic change around the Indian Oceant in the very long run, Venice, 2008, 5-8.

[9] S. Dercon, On market integration and liberalization: method and application to Ethiopia, Journal of Development Studies, 32, 1995, $112-143$.

[10] D. Dickey and W. Fuller, W. (1979). Distribution of the estimators for autoregressive time series with a unit root, Journal of the American Statistical Association, 74, 1979, 427-431.

[11] R. F. Engle and C.W.J. Granger, Co-integration and error correction: Representation, estimation and testing, Econometrica, 55, 1987, 251-276.

[12] M. Ghosh, Cointegration tests and spatial integration of rice markets in India, Indian Journal of Agricultural Economics, 55(4), 2000, 616-625.

[13] D. N. Gujarati, Basic econometrics (3rd Ed, McGraw Hill, Inc., Singapore, 1995).

[14] B. Harriss, There is method in my madness: or it is vice-versa? Measuring agricultural market performance." Food Research Institute Studies, 27(2), 1979, 97-218.

[15] J. K. Huang and S. Rozelle, The emergence of agricultural commodity markets in China, China Economic Review 17, 2006, 26680.

[16] S. Johansen and K. Juselius, Maximum likelihood estimation and inference on cointegration-with application to the demand for money, Oxford Bulletin of Economic Statistics 52(2), 1990, 169-210.

[17] W. O. Jones, The structure of staple food marketing in Nigeria as revealed by price analysis, Food Research Studies Institute, 8(2), 1968, 95-124.

[18] K. Juselius, The Co-integrated VAR Model: Methodology and applications, Oxford University Press (manuscript), 2006.

[19] P. B. Jyotish, Cointegration and market integration: An application to the potato markets in Rural West Bengal, India. Paper presented at the International Association of Agricultural Economists conference, Gold Coast, Australia, August 12-18, 2006.

[20] T. E. Mafimisebi, Long-run price integration in the Nigerian fresh fish market-implications for marketing and development. Delhi Business Review 9(1), 2008, 55.

[21] H. Mohammad and W. Verbeke, Evaluation of Rice Markets Integration in Bangladesh, The Lahore Journal of Economics 15 (2), 2010, 77-96.

[22] G. O. Odularu, Rice Trade Policy Options in an Open Developing Economy: The Nigerian Case Study, Journalof Development and

[23] Agricultural Economics 2(5), 2010, 166-17.

[24] R. N. Okoh and P. C. Egbon (2005). The integration of Nigeria's rural and urban foodstuffs markets. AERC Research Paper, African Economic Research Consortium, Nairobi, 2005, 151.

[25] O. N. Okoroafor, R.N. Echebiri, and I.N. Nwachukwu, Demand for fertilizer in Nigeria: an application of co-integration and error correction modelling. Journal of Agriculture and Social Research 10(2),2010.

[26] M. A. Y. Rahji and M. O. Adewunmi, Market supply response and demand for local rice in Nigeria: Implications for selfsufficiency policy, Journal of central European Agriculture 9(3), 2008, 567-573.

[27] M. Ravallion, Testing market integration, American Journal of Agricultural Economics 68(1), 1986, $102-109$.

[28] M. Tahir Mukhtar and Muhammad Javed, Price integration in wholesale maize markets in Pakistan, The Pakistan Development Review 46(2), 2007, 1075-1084.

[29] S. Takamatsu, Economic analysis of rice market integration in Laos. A Master's Thesis presented to the Graduate School of International Cooperation Studies, Kobe University, Laos, 2002.

[30] C. P. Timmer, Food security and economic growth: an Asian perspective, Center for global development Working Paper 51, 2004. 